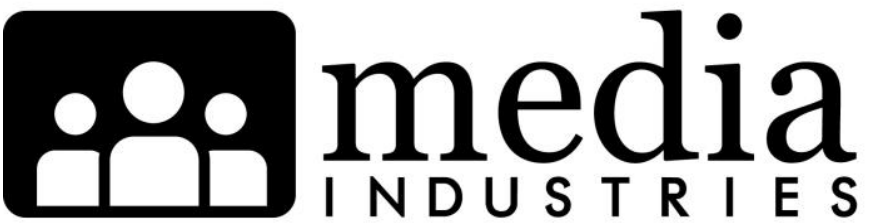

\section{Assembling a Toolkit}

\author{
Amanda D. Lotz 1 \\ University of Michigan \\ lotz [AT] umich.edu
}

\begin{abstract}
:
Media industries scholarship reaches an important benchmark with the establishment of its own focused journal. The strength of this area of inquiry is its range of intellectual foci and scholarship priorities, which a publication outlet such as Media Industries should endeavor to keep vibrant. Rather than view the relative youth and breadth of approaches to media industry studies as a weakness, this essay identifies the existing variation in approaches, methods, foci, and central theories to studying media industries as a useful strategy that should be maintained as benchmarks of institutionalization are achieved.
\end{abstract}

Keywords: Cultural Studies, Research Methods

The study of media industries is developing at a time of constant change in the nature of media and how they are made. Only those who study historical media operations are free to assume that the norms in place at the start of a study will persist to the end. The media industries are being remade and reorganized in profound ways and, though growing more multifaceted, seem only likely to play an increasingly greater role in the lives of individuals and cultures around the globe. These changes are both exciting and challenging for those endeavoring to research them.

Such an environment requires practices of research as dynamic and multifaceted as the industries we study. Fortunately, there is little about media industry studies that is established or entrenched. There were no "media industries" courses available when I studied at the University of Texas at Austin in the late 1990s. Indeed, my collaboration with Tim Havenswith whom I wrote Understanding Media Industries - dates to the early 2000s, when we both struggled to inform our developing scholarship with an "industry" perspective and to figure out how to teach these concepts to undergraduate students. ${ }^{2}$ I can still remember the sense of being adrift, of searching for a coherent intellectual body within which to place my work, and of clinging to publications that began to offer an approach to media industries that was different than political economy; as that was long the problem, I knew the questions I wanted to ask of media industries weren't those primary among those defining "political economy" at the time, but had no alternative name for it. I assigned a long series of overly demanding books to shellshocked undergrads in those years (Eric Louw's The Media and Cultural Production, David Hesmondhalgh's The Cultural Industries) or taught material already outdated (Joseph Turow's 
Media Systems in Society) or just not what I really wanted to teach (Croteau and Hoynes's The Business of Media, as well as various media economics texts). ${ }^{3}$ But a decade after I had completed my degree, I taught my first graduate media industries class and had a wealth of material to choose from, as Holt and Perren's Media Industries and Mayer, Banks, and Caldwell's Production Studies were freshly in print and suggested the vibrant conversation increasingly moving from the peripheries into a dynamic subfield. 4

The point of this detour through a personal aside is to offer some context for my perception that quite substantial change in the study of media industries has developed in a very short period of time. Certainly the creation of a journal such as this one suggests a next stage of development and intellectual institutionalization. Though some might be tempted to seek legitimacy by following paths charted in other fields and disciplines through a survival-of-the-fittest, zerosum battle to determine the canon, approach, and most worthy ideas for studying media industries, here I simply suggest, let's not. Though it might seem that greater cohesion in intellectual endeavors is a mark of a maturing subfield, I would argue: not so. Rather than view the relative youth and variation of the subfield as a deficit, I view our lack of orthodoxy in training, annual meetings, or publication outlet as a strength. Though it might at times seem like the establishment of traditions, standards, and norms provide the next steps toward a more profound presence in the field, there remains great advantage to maintaining dynamic and multifaceted perspectives on this work.

To be sure, the arrival of a journal called Media Industries should not become the and only place where scholarship about media industries is published. Its editors and editorial boards will have tendencies and intellectual proclivities that help shape, but should not alone define, the emerging subfield. Such a journal creates more venues for publication of media industries work and likely allows opportunities for cross-pollination less feasible in the existing journals that publish industry studies, but also a broad range of other media scholarship.

Approaches identified as media industries, production studies, media sociology, and the many others claimed by scholars are valuable for the range of tools their foci provide and should not be considered to be in some competitive death match to become the approach to media industry study. Rather, they are made stronger by continued independence and theory building that expands their outlooks and our perspectives on what we can claim to know about media industries and how we arrive at this knowledge. The relative value of these approaches is determined only by the research question at hand. Researchers choose among these tools based on their priorities in the intellectual process. A desire to focus on one area should not be assumed as a categorical disavowal of others. All studies in all approaches are necessarily partial. It is only through conversation across approaches that those bits of knowledge can grow into something larger.

There is much we don't fully understand about how media industries have operated or how they operate today. No one can know how they will operate going forward, though the furious and constant change of the present captures popular and academic fascination alike. As scholars, we have the luxury of taking the long view - of not having the daily deadlines of industry press and bloggers or the weighty pressure of quarterly profit considerations of those working in these industries. This luxury requires that we-regardless of approach-pursue more substantive work than the cataloging of events and developments. We must bring new knowledge by situating events in a historical context, by casting a skeptical eye on the dominant discourses that emerge in superficial trade accounts, and by remembering that the burden of 
scholarly work is a requirement to articulate a "so what" regarding the matter at hand. The media industry scholar must consider the implications of a multiplicity of industrial practices such as new technologies, distribution routes, production practices, and economics for a whole range of groups - audiences, creatives, executives, below-the-line workers, even stockholderseven if we write accounts that are more narrowly focused.

Each subtle change in industrial practices brings many unforeseen and unconsidered effects. We must try to see or imagine the "big picture," and doing so requires all levels of inquiry and analysis in our efforts to devise sophisticated understandings of how media industries work and why and how changes in industrial practices affect texts in meaningful ways. Though academic inquiry tends to prioritize analysis, there is much work to be done in first developing more basic descriptive knowledge of actual operations from which to build empirically based analyses. While the youth of media industries studies is an advantage in its lack of entrenched orthodoxies of approach, it also means that there is a great, great deal that we do not truly know. Even many of the things we think we know - such as that advertisers exert influence on the content they advertise in - we don't really know in detail. Many assume a simple process of advertisers objecting to content, when in practice the nature and process by which advertising is sold-in which buyers attend not so much to content but to spreadsheets of demographic data-requires a more nuanced understanding. Of course this is not to say that advertisers don't exert influence: they do so much more by what they don't say or do and through the selfregulation content providers perform in anticipation of advertiser reaction. Simple assumptions of conservative and homogeneous advertisers have prevented interrogation of organizational practices and the acculturation of workers to develop more nuanced understandings. Concepts such as "industry lore" and "discerned savvy" suggest valuable preliminary theory building based in particular sites that might nevertheless prove useful across media contexts. ${ }^{5}$

A robust future for the study of media industries does not require dogmatic adherence to a particular tradition or outlook so much as flexibility that matches research questions and research methods and draws from a vast toolkit of techniques for inquiry. Certainly the naming of a subfield leads toward a tendency of boundary policing: this is what we are or are not; we use these theories or methods, not those. Media industry studies will do well to emphasize its object of study - that of practices and processes of text creation and circulation that precede, although are constitutive of, audience creation. The question should be whether an aspect of these practices and processes is at the core of inquiry, not adherence to a particular approach that determines what is a part of media industry studies. Of course, some of the best work often extends beyond production and industrial operation to unite these practices with analysis of the object created or the response of those engaged by it. Here too, let media industries approach its object broadly.

1 Amanda D. Lotz is Associate Professor of Communication Studies at the University of Michigan. She is the author of Cable Guys: Television and American Masculinities in the 21st Century (New York University Press, 2014), The Television Will Be Revolutionized (New York University Press, 2007, 2014) and Redesigning Women: Television after the Network Era (University of Illinois Press, 2006) and editor of Beyond Prime Time: Television Programming in the Post-Network Era (Routledge, 2009). She is coauthor, with Timothy Havens, of Understanding Media Industries (Oxford University Press, 2011, 2015) and, with Jonathan Gray, of Television Studies (Polity, 2011). 
2 Timothy Havens and Amanda D. Lotz, Understanding Media Industries (New York: Oxford University Press, 2011).

3 Eric Louw, The Media and Cultural Production (London: Sage, 2001); David Hesmondhalgh, The Cultural Industries (London: Sage, 2002); Joseph Turow, Media Systems in Society: Understanding Industries, Strategies, and Power, 2nd ed. (White Plains, NY: AB Longman, 1997); David Croteau and William Hoynes, The Business of Media: Corporate Media and the Public Interest (Boston: Pine Forge Press, 2001).

4 Jennifer Holt and Alisa Perren, Media Industries: History, Theory, and Method (Malden, MA: Wiley-Blackwell, 2009); Vicki Mayer, Miranda J. Banks, and John Thornton Caldwell, Production Studies: Cultural Studies of Media Industries (New York: Routledge, 2009).

5 Timothy Havens, "Toward a Structuration Theory of Media Intermediaries," in Making Media Work: Cultures of Management in the Entertainment Industries, ed. Derek Johnson, Derek Kompare, and Avi Santo (New York: New York University Press, 2014); Jimmy Draper, "Theorizing Creative Agency through 'Discerned Savvy': A Tool for the Critical Study of Media Industries," Media, Culture, and Society 36 no. 8(2014): 11181133.

\section{Bibliography}

Croteau, David, and William Hoynes. The Business of Media: Corporate Media and the Public Interest. Boston: Pine Forge Press, 2001.

Draper, Jimmy. "Theorizing Creative Agency through 'Discerned Savvy': A Tool for the Critical Study of Media Industries." Media, Culture, and Society 36 no. 8 (2014): 1118-1133.

Havens, Timothy. "Toward a Structuration Theory of Media Intermediaries." In Making Media Work: Cultures of Management in the Entertainment Industries, edited by Derek Johnson, Derek Kompare, and Avi Santo. New York: New York University Press, 2014.

Havens, Timothy, and Amanda D. Lotz. Understanding Media Industries. New York: Oxford University Press, 2011.

Hesmondhalgh, David. The Cultural Industries. London: Sage, 2002.

Holt, Jennifer, and Alisa Perren. Media Industries: History, Theory, and Method. Malden, MA: Wiley-Blackwell, 2009.

Louw, Eric. The Media and Cultural Production. London: Sage, 2001.

Mayer, Vicki, Miranda J. Banks, and John Thornton Caldwell. Production Studies: Cultural Studies of Media Industries. New York: Routledge: 2009.

Turow, Joseph. Media Systems in Society: Understanding Industries, Strategies, and Power. 2nd ed. White Plains, NY: AB Longman, 1997.

\section{(cc) BY-NC-ND}

Copyright (C) 2015 (Amanda Lotz). Media Industries is an open-access, peer-reviewed, online academic journal. As such, we aim to participate in the open exchange of information. This work is licensed under a Creative Commons Attribution Noncommercial No Derivatives (by-nc-nd) License. Under this license, this work is available for sharing and noncommercial distribution provided the appropriate attribution is given. 